\title{
OPTIMALISASI WEB SERVER MENGGUNAKAN SYSTEM FAILOVER CLUSTERING BERBASIS CLOUD COMPUTING
}

\author{
Muhajirin' \\ Program Studi Teknik Informatika \\ STMIK AKBA \\ Jalan Perintis Kemerdekaan, Makassar \\ Email: aji@akba.ac.id
}

\begin{abstract}
ABSTRAK
Salah satu penyebab kegalan server melayanani client adalah karena hanya satu server sebagai pusat data yang melayani berbagai permintaan data dari komputer client. Penelitian ini bertujuan merancang dan mengimplementasikan System Failover Clustering berbasis Cloud Computing Pada Web Server. Data ini diperoleh melalui Penelitian Lapangan, Penelitian Pustaka dan Wawancara. Data itu dianalisis dengan menggunakan metode Network Development Life Cycle. Hasil penelitian ini menunjukkan bahwa server yang dibangun menggunakan System Failover Clustering cukup signifikan dari segi availability dan skalabilitas apabila terjadi failureldowntime pada server yang sedang aktif maka layanan akan berpindah ke server pasif kemudian berubah menjadi server aktif sehingga akses/permintaan koneksi dari client tidak terputus. Kemudian dari segi keamanan data, resiko kehilangan data dapat ditiadakan karena semua data tersimpan pada kedua server.
\end{abstract}

\section{Kata Kunci: Web Server, Client, Komputer Cloud, Failover Clustering}

\begin{abstract}
One cause of the failure of servers serving client is because only one server as a data center that serves a variety of requests for data from the client computer. This research aims to design and implement System Failover Clustering based Cloud Computing On the Web Server. This data was obtained through field research, library research and interviews. Data was analyzed using the methods Network Development Life Cycle. The results of this study indicate that the server is built using System Failover Clustering significant enough in terms of availability and scalability in the event of failure / downtime on a server that is active then the service will be moved to the server passively later became active server so that access / connection requests from clients are not disconnected, Then in terms of data security, risk of data loss can be eliminated because of all the data stored on both servers.
\end{abstract}

Keywords: web server, client, cloud computing, failover clustering 


\section{PENDAHULUAN}

Meningkatnya kebutuhan belanja Teknologi Informasi (TI) seiring dengan perkembangan infrastruktur TI secara global menuntut perusahaan melakukan inovasi terkait penghematan anggaran, ini pula yang biasa menyebabkan perusahaan melakukan pemangkasan pada beberapa unit investasi, mulai dari pengurangan jumlah karyawan, biaya perjalanan bisnis, bahkan disisi lain para perusahaan juga menekan pengeluaran serta memaksimalkan investasi Teknologi \& Informasi (TI).

Wacana komputasi awan (yang selanjutnya lebih dikenal dengan istilah Cloud Computing) semakin banyak dimanfaatkan sebagai solusi memaksimalkan resource dalam dunia TI, terutama dalam isu penghematan anggaran perusahaan. Salah satunya adalah teknologi Cloud Computing yang didalamnya terdapat Platform virtualisasi dan Cluster Server yang menjamin ketersediaan layanan yang tinggi karena semua data ditampung ke dalam Server data yang High Availability. Semua data bisa diakses melalui Web, sehingga Cloud Computing ini merupakan solusi komputasi.

CV Smart Inovasi sebagai salah satu perusahaan yang bergerak dibidang TI telah menerapkan sebuah webserver untuk keperluan pelayanan aplikasi berbasis web. Akan tetapi, Penggunaan webserver tunggal tentunya beresiko dengan tidak adanya mekanisme backup dan gangguan-gangguan lainnya berupa kerusakan device, storage, data corruption, lost network yang dapat menyebabkan server mengalami downtime. Dalam perancangan sistem failover clustering ini digunakan sistem operasi Proxmox Virtual Environment (Proxmox VE) sebagai central manager dari sistem Cloud Computing yang akan dibuat, karena kehandalan sistem serta fasilitas kustomisasi yang lengkap.

Skenario tersebut merupakan salah satu objek yang bisa diselesaikan dengan implementasi konsep Cloud Computing dengan model penyebaran Private Cloud. Pemanfaatan teknologi ini tentunya memudahkan administrator dalam mengelola sistem yang ada secara efisien.

\section{TINJAUAN PUSTAKA}

\section{Clustering Computing}

Lysy C. Moleong, Arthur M. Rumagit dan Brave A. Sugiarso[1] mendefenisikan Cluster Computer adalah kumpulan dari komputerkomputer yang terkoneksi melalui jaringan lokal berkecepatan tinggi dan didesain untuk digunakan sebagai sumber daya komputasi yang terintegrasi atau sumber daya untuk pemrosesan data. Sebuah cluster memiliki beberapa karakteristik antara lain : terdiri dari beberapa mesin-mesin bertipe sama, Tightlycoupled menggunakan koneksi jaringan yang dedicated, semua mesin berbagi sumber daya contohnya adalah direktori home, harus percaya satu sama lain sehingga rsh maupun ssh tidak memerlukan password, harus mempunyai software seperti implementasi MPI yang memungkinkan program-program dijalankan disemua node. Clustering terbagi dalam beberapa jenis yaitu high availability cluster, load balancing cluster dan grid computer.

\section{Web Server}

Alexander F.K. Sibero [2] mendefinisikan web server adalah sebuah komputer yang terdiri dari perangkat keras dan perangkat lunak. Secara bentuk fisik dan cara kerjanya perangkat keras web server tidak berbeda dengan komputer rumah atau PC, yang membedakan adalah kapasitas dan kapabilitasnya. Perbedaan tersebut dikarenakan web server bekerja sebagai penyedia layanan yang dapat diakses oleh banyak pengguna, sehingga dibutuhkan kapasitas dan kapabilitas yang besar dibandingkan PC. Hubungan perangkat lunak sangat dibutuhkan agar web server dapat berjalan secara optimal. Setiap perangkat lunak web server memiliki karakteristik dan teknologi yang digunakan untuk mengatur kerja sistemnya

\section{Cloud Computing}

Iwan Sofana [3] menjelaskan Cloud Computing adalah sebuah model client-server, dimana resource seperti server, storage, network, dan software dapat dipandang sebagai layanan yang dapat diakses oleh pengguna secara remote dan setiap saat. Pengguna dapat menikmati berbagai layanan yang disediakan oleh provider cloud computing, tanpa perlu terlalu banyak meminta bantuan teknis atau support dari pihak provider. Infrastruktur cloud computing seperti: server, storage, network, dan berbagai software disebut "cloud".

I Putu Agus Eka Pratama [4], Komputasi awan (Cloud Computing) adalah gabungan antara pemanfaatan teknologi komputer dengan pengembangan berbasis internet. Awan (cloud) adalah metafora dari internet, sebagaimana awan yang sering digambarkan pada diagram jaringan komputer. Selain seperti awan dalam diagram jarigan komputer, awan (cloud) dalam Cloud Computing juga merupakan abstraksi dari infrastruktur yang disembunyikannya. Cloud Computing menerapkan suatu metode komputasi, yaitu kapabilitas yang terkait teknologi informasi disajikan sebagai suatu layanan/service sehingga pengguna dapat mengaksesnya lewat internet, tanpa mengetahui apa yang ada didalamnya, ahli dengannya, atau memiliki kendali terhadap infrastruktur teknologi yang membantunya. 


\section{Optimalisasi}

Muhammad Aidi Ali [6] mengemukakan bahwa optimalisasi adalah hasil yang dicapai sesuai dengan keinginan, jadi optimalisasi merupakan pencapaian hasil sesuai harapan secara efektif dan efisien.

\section{Failover Clustering}

Nanang Purnomo dan Melwin Syafrizal [5] mengemukakan Failover cluster merupakan sekumpulan server yang saling bekerjasama untuk memberikan pelayanan meskipun berada ditempat yang berbeda, dan memiliki kualitas data atau sumberdaya yang sama antara server yang satu dengan serverlainnya

\section{METODE PENELITIAN}

\section{Analisis Kebutuhan Sistem}

T. Sutabri [9] mengemukakan Analisis Sistem adalah penguraian suatu sistem informasi yang sudah utuh kedalam bagian-bagian komponennya dengan tujuan dapat menidentifikasi dan menevaluasi berbagai macam permasalahan maupun hambatan yang terjadi pada sistem sehingga nantinya dapat dilakukan perbaikan atau pengembangan.

Untuk mempermudah jalannya penelitian maka dibutuhkan spesifikasi komputer yang mampu menangani fungsi dari tugas komputer Server sebagai komponen utama untuk membangun Cloud Computing. Sedangkan komputer client bisa menggunakan komputer dengan spesifikasi standar tanpa memerlukan settingan khusus. Selain membahas hardware yang dibutuhkan juga akan dibahas software atau aplikasi apa saja yang dibutuhkan sehingga sistem dapat berjalan secara utuh dan lancarsesuai dengan batas minimum untuk membangun sebuah virtualisasi cloud computing yang utuh dan dapat dimanfaatkan sebagaimana mestinya yang diharapkan.

\section{Kebutuhan Perangkat}

1. Perangkat Keras (Hardware)

Dalam perancangan dan implementasi Server cloud ini, spesifikasi komputer yang akan digunakan sebagai berikut:

a. Komputer Server

1) Processor teknologi VT (Virtualization Technologi) Dual Core

2) Hardisk $750 \mathrm{~GB}$

3) 4 GB ram

4) Ethernet Card 10/100 Mbps

b. Kabel UTP

c. Konektor RJ 45

d. Hub

2. Aspek Perangkat Lunak (Software)

Untuk membangun Virtualisasi Server Cloud Computing ini membutuhkan beberapa perangkat lunak atau software, antara lain: a. Proxmox VE (Virtual Environment)

b. Browser Mozilla Firefox

c. Image sistem operasi (ISO) Ubuntu

\section{Metode Pengumpulan Data}

Jenis pengumpulan data yang digunakan pada penelitian ini meliputi:

1. Field Research

Terdapat dua teknik pengumpulan data yang digunakan pada jenis field research, yaitu:

a. Teknik observasi

Teknik observasi merupakan teknik yang dilakukan dengan cara pengamatan langsung ke lokasi penelitian. Data yang dikumpulkan berupa skema jaringan yang digunakan, peralatan yang digunakan serta jumlah komputer yang terhubung dalam sebuah jaringan.

b. Teknik Dokumentasi

Teknik dokumentasi merupakan teknik yang digunakan untuk mengumpulkan data - data profil objek penelitian berupa sejarah singkat, struktur organisasi, serta visi dan misi.

2. Library Research

Library Research merupakan jenis pengumpulan data yang diperoleh melalui dokumen-dokumen dan buku-buku atau literatur literatur lainnya yang relevan dengan masalah yang diteliti.

\section{Analisis Kelayakan}

Pengujian sistem dimaksudkan untuk menentukan apakah sistem yang akan kita buat layak untuk digunakan atau tidak oleh sebuah instansi terkait. Sebuah studi kelayakan akan menilai dari berbagai sisi, apakah sistem memang layak untuk diimplementasikan. Penilaian tersebut antara lain:

a. Kelayakan Ekonomi

Pengurangan biaya investasi hardware dapat ditekan lebih rendah karena konsep virtualisasi hanya mendayagunakan kapasistas yang sudah ada. Tak perlu penambahan perangkat komputer, Server dan pheriperal secara fisik. Kalaupun ada penambahan kapasitas hardisk dan memori, itu untuk mendukung stabilitas kerja sebuah komputer Server, yang jika dihitung secara finansial masih jauh lebih hemat dibandingkan investasi untuk penambahan komputer Server terbaru dan mengurangi biaya space ruang penyimpanan. Semakin sedikit jumlah Server semakin sedikit pula ruang untuk menyimpan perangkat serta mengurangi biaya operasional.

b. Kelayakan Operasional

Proses penggantian dan upgrade spesifikasi Server lebih mudah dilakukan. Jika salah satu Server sudah overload dan spesifikasinya tidak mencukupi lagi, kita bisa dengan mudah melakukan upgrade spesifikasi pada salah satu Server tanpa memutus layanan Server ke client sebab layanan telah dialihkan pada second Server. 


\section{Perancangan Sistem}

Berdasarkan dari hasil observasi dan pengambilan data ditempat penelitian serta ditemukannya masalah yang telah dibahas sebelumnya, peneliti memberikan atau melakukan percobaan dengan membuatkan sebuah solusi yaitu berupa rancangan system failover clustering berbasis cloud computing. Adapun rancangannya seperti pada gambar 1:

$$
\text { Aktif Server/ Proxmox } 1
$$

Passive Server / Proxmox 2

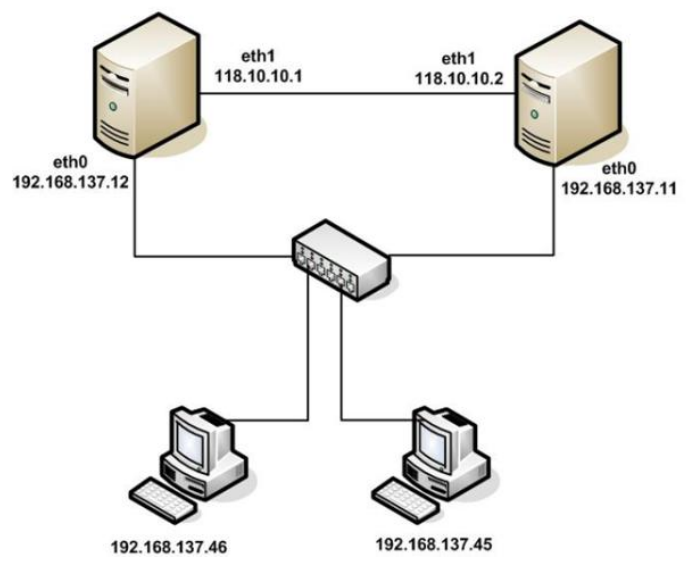

Gambar 1 Rancangan Topologi Failover Clustering

\section{Teknik Pengujian}

Teknik pengujian yang digunakan dalam penelitian ini adalah black-box testing. Abdul Rouf [7] dalam penelitiannya menyatakan pengujian blackbox bertujuan untuk mengetahui apakah semua fungsi perangkat lunak telah berjalan semestinya sesuai dengan kebutuhan fungsional yang telah didefinsikan.

Janner [8] menyatakan Black-box testing berfokus pada persyaratan fungsional perangkat lunak. Metode ini memungkinkan software developer untuk mendapatkan serangkaian kondisi input yang mempergunakan semua persyaratan fungsional program. Black-Box testing bukan alternatif white-box testing, namun merupakan pelengkap yang mampu mengungkap kesalahan, jika dibandingkan metode white-box testing. Adapun gambaran pengujian blackbox seperti pada gambar 2:

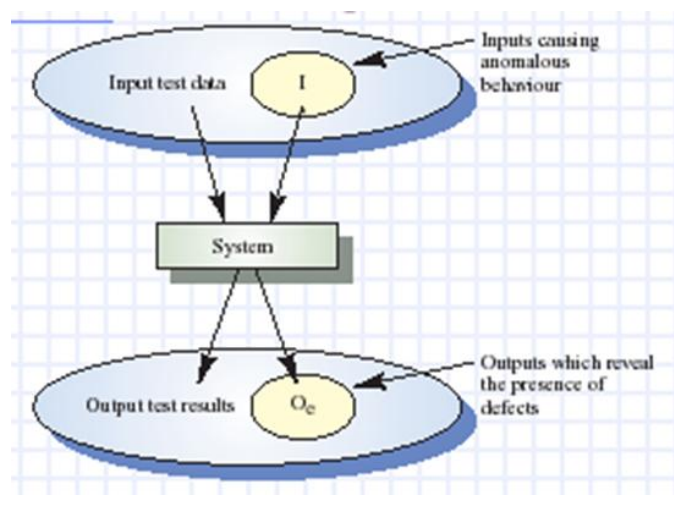

Gambar 2. Black-box Testing

Pengujian black-box berusaha menemukan kesalahan dalam kategori:

1. Fungsi - fungsi yang tidak benar atau hilang

2. Kesalahan interface

3. Kesalahan dalam struktur data atau akses database eksternal

4. Kesalahan kinerja

5. Inisialisasi dan kesalahan terminasi

Equivalence partitioning yaitu metode pengujian black-box yang membagi domain input dari suatu program ke dalam kelas data dari mana test case dapat dilaksanakan. Input data dan output hasil terdapat di kelas yang berbeda yang sesuai dengan kelas inputnya. Masing-masing kelas equivalensi partition diproses dimana program akan memproses anggota kelas-kelas tersebut secara equivalen. Test cases dipilih dari masing-masing partisi.

\section{HASIL PENELITIAN}

Pada tahap kali ini adalah melakukan pengujian atau benchmarking pada sistem failover clustering yang telah dibuat pada kedua server. Pengujian pertama yaitu menguji apakah failover clustering benar benar berjalan pada kedua server. Pengujian kedua yaitu melakukan proses benchmarking menggunakan software HTTPERF yang di instal pada VM yang merupakan sistem informasi virtual sebagai server yang diakses oleh client. Adapun parameter yang diukur dengan software tersebut yaitu availability, downtime, CPU Utilization, Throughput.

\section{Pengujian Failover Clustering}

Pada pengujian ini yaitu dengan melakukan proses update data pada storage dengan memasukkan sebuah website beserta database kemudian dilakukan penginputan data melalui website tersebut dan disimpan pada storage. Proses ini dilakukan pada server yang sedang aktif atau sebelum terjadinya failure/downtime. Setelah itu dilakukan failure yang disengaja pada server aktif untuk mengecek apakah data yang telah diinput masih dapat diakses pada server yang sebelumnya berstatus pasif menjadi aktif. Berikut adalah hasil pengujiannya: 


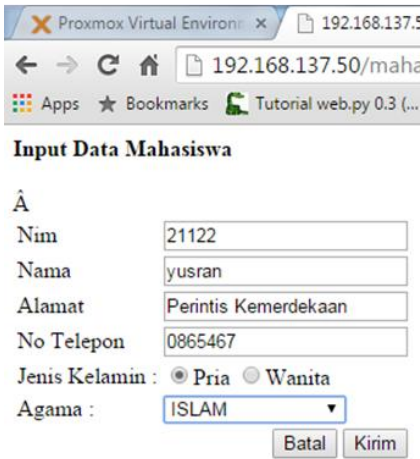

Gambar 3 Input Data Pada Melalui Server1

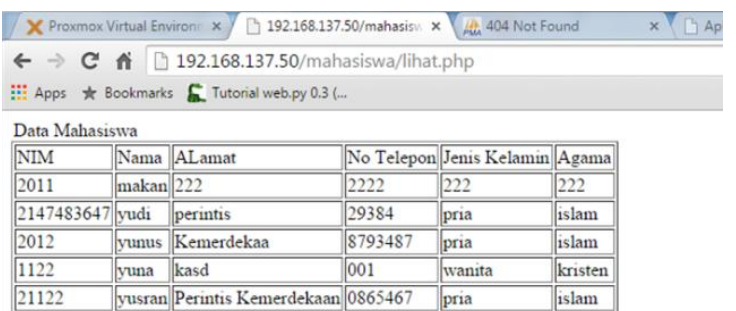

Gambar 4 Hasil Input Data Pada Melalui Server1

Pada Gambar 3 dilakukan penginputan data pada Server1 atau Server aktif dan pada Gambar 4 adalah hasil input data pada Server1.

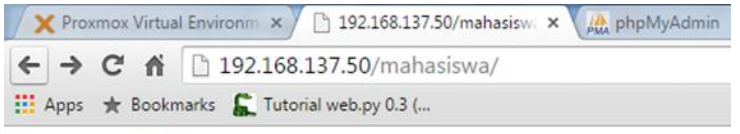

Input Data Mahasiswa

$\hat{\mathrm{A}}$

$$
\begin{aligned}
& \text { Nim } 2113 \\
& \text { Nama Ni Ketut Yuliana } \\
& \text { Alamat BTP } \\
& \text { No Telepon } 09876364 \\
& \text { Jenis Kelamin : Pria } \odot \text { Wanita } \\
& \text { Agama : HINDU } \\
& \text { Batal Kirim }
\end{aligned}
$$

Gambar 5 Input Data Pada Melalui Server2

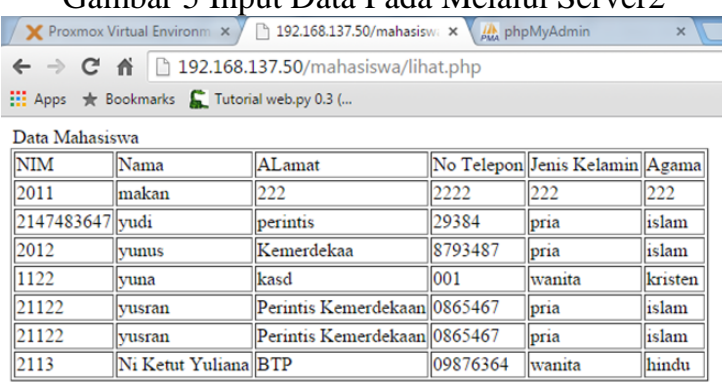

Gambar 6 Input Data Pada Melalui Server2

Pada Gambar 5 dilakukan penginputan data pada Server2 setelah terjadinya failure/downtime dan pada Gambar 6 adalah hasil input data pada Server2. Kesimpulan dari pengujian ini adalah system failover clustering yang telah dibangun dapat berjalan dengan baik. Website tersebut dapat diakses kemudian dilakukan proses update atau input data pada kedua server.

\section{Analisa Availabilty}

Tingkat availability diukur berdasarkan istilah "nine", dimana semakin banyak "nine" maka semakin tinggi sebuah sistem availability. Istilah "nine" digunakan karena tidak ada sistem yang mendapatkan ketersediaan seratus persen. Availability dapat digunakan sebagai salah satu parameter dalam Service Level Agreement (SLA). SLA adalah perjanjian yang disepakati antara penyedia layanan dengan pengguna dalam ruang lingkup untuk menentukan karakteristik dan kualitas layanan yang akan diberikan.

Pengujian availability pada penelitian ini tidak mengambil waktu sebelum terjadi kegagalan sistem ataupun sesudah kegagalan sistem. Tetapi mengamati apakah layanan server tetap berjalan saat terjadi kegagalan pada salah satu server virtual. Perhitungan availability cluster berdasarkan rumus yang digunakan oleh Braastad (2006) Calzolari (2009) seperti berikut:

\section{Availability $=\frac{M T B F}{M T B F+M T T R} \times 100 \%$}

a. Mean Time Between Faults

(MTBF) merupakan waktu rata-rata uptime.

\begin{tabular}{|c|c|c|c|c|}
\hline Waktu & $\begin{array}{l}\text { Sebab } \\
\text { gagal }\end{array}$ & $\begin{array}{l}\text { MTBF } \\
\text { (Mnt) }\end{array}$ & $\begin{array}{l}\text { MTTR } \\
\text { (Mnt) }\end{array}$ & $\begin{array}{l}\text { Availa- } \\
\text { bility }\end{array}$ \\
\hline $8-8-15$ & $\begin{array}{l}\text { Server } \\
\text { Down }\end{array}$ & 2735 & 0.5 & $99.98 \%$ \\
\hline $9-8-15$ & $\begin{array}{l}\text { Server } \\
\text { Down }\end{array}$ & 7139 & 0.7 & $99.99 \%$ \\
\hline $10-8-15$ & $\begin{array}{c}\text { Listrik } \\
\text { mati }\end{array}$ & 1732 & 112 & $93.92 \%$ \\
\hline $11-8-15$ & $\begin{array}{l}\text { Server } \\
\text { Down }\end{array}$ & 4672 & 1.0 & $99.94 \%$ \\
\hline $12-8-15$ & $\begin{array}{c}\text { Listrik } \\
\text { mati }\end{array}$ & 3660 & 16 & $99.56 \%$ \\
\hline $\begin{array}{l}\text { Nila } \\
\text { Avai }\end{array}$ & $\begin{array}{l}\text { Гotal } \\
\text { bility }\end{array}$ & 19938 & 130.2 & $99.35 \%$ \\
\hline
\end{tabular}

b. Mean Time to Repair (MTTR) merupakan ratarata waktu yang diperlukan untuk mengembalikan layanan tabel 1:

Hasil pengujian availability dapat dilihat pada

Tabel 1Hasil Pengujian Availabilty

Berdasarkan nilai benchmark pada Tabel 1 untuk analisa pengujian availability hasilnya mendekati 0 dan dapat dikatakan zero downtime. Karena delay yang terjadi pada pengujian availability tersebut memiliki nilai rata-rata delay dalam 5 hari sebesar 26 menit dengan tingkat availability total mencapai $99,35 \%$.

\section{Analisa Downtime}

Peni Nala Sari [10] mengemukakan Downtime adalah jumlah waktu dimana suatu equipment tidak dapat beroperasi disebabkan adanya kerusakan (failure), namun pabrik masih dapat beroperasi 
karna masih adanya equipment lain yang bisa menggantikan fungsi sehingga proses produksi masih bisa berjalan.. Downtime sangat berpengaruh pada nilai availability dari suatu equipment, tetapi belum tentu berpengaruh pada Loss Time. Hasil pengujian pada skenario downtime diambil dari pengujian availability dengan menghitung antara waktu sebelum failover atau Mean Time Between Faults (MTBF) sampai dengan waktu sebelum mengembalikan layanan atau Mean Time to Repair (MTTR). Hasil pengujiannya seperti tabel 2:

Tabel 2 Hasil Pengujian Downtime

\begin{tabular}{|c|c|c|c|c|}
\hline No & $\begin{array}{l}\text { Sebab } \\
\text { Gagal }\end{array}$ & $\begin{array}{c}\text { Failover } \\
\text { (Mnt) }\end{array}$ & $\begin{array}{l}\text { Delay } \\
\text { (Mnt) }\end{array}$ & $\begin{array}{c}\text { Failback } \\
\text { (Mnt) }\end{array}$ \\
\hline 1 & $\begin{array}{l}\text { Server } \\
\text { Down }\end{array}$ & 2735 & 0.5 & 2735.5 \\
\hline 2 & $\begin{array}{l}\text { Server } \\
\text { Down }\end{array}$ & 7139 & 0.7 & 7139.7 \\
\hline 3 & $\begin{array}{c}\text { Listrik } \\
\text { mati }\end{array}$ & 1732 & 112 & 1844 \\
\hline 4 & $\begin{array}{l}\text { Server } \\
\text { Down }\end{array}$ & 4672 & 1.0 & 4673 \\
\hline 5 & $\begin{array}{c}\text { Listrik } \\
\text { mati }\end{array}$ & 3660 & 16 & 3676 \\
\hline
\end{tabular}

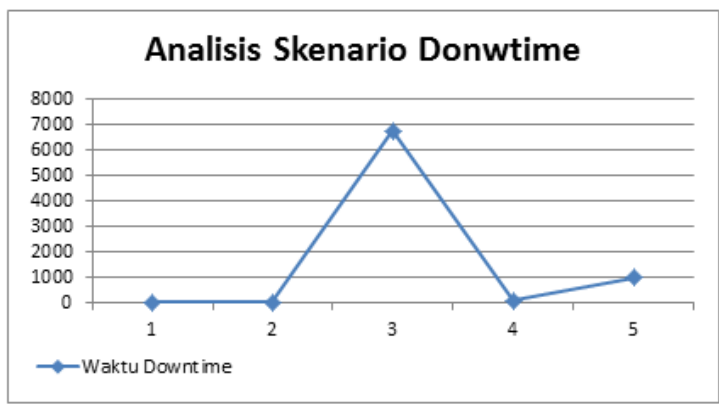

Gambar 7 Grafik Analisis Skenario Downtime

Berdasarkan hasil pengujian layanan web server pada tabel 1 dan grafik pada gambar 7 menunjukkan bahwa besarnya persentase availability server mempengaruhi lamanya waktu downtime yang dialami cluster server. Semakin besar tingkat availability server maka semakin cepat yang dibutuhkan oleh server cluster untuk mengembalikan layanan atau failback ketika terjadi kegagalan pada server utama, begitu juga sebaliknya. Waktu failback tercepat didapatkan ketika server mengalami kegagalan akibat web server downtime dengan waktu failover 2735 detik dan waktu yang dibutuhkan untuk mengembalikan layanan atau failback adalah 2735.5 detik dengan lama waktu downtime 5 detik. Waktu terlama downtime terjadi ketika server mengalami gangguan listrik mati yaitu dengan lama downtime 6720 detik atau 112 menit.

\section{Analisa Parameter CPU Utilization}

CPU usage atau CPU time dari sebuah program adalah lama waktu penggunaan prosesor yang diperlukan program untuk menjalankan instruksiinstruksinya. Pengujian analisa CPU Utilization dilakukan pada kedua sisi server cluster dengan menggunakan httperf. Pengujian ini dilakukan dengan dua skenario berbeda. Skenario pertama adalah testing dilakukan pada saat semua nodes cluster dalam kondisi up. Skenario kedua saat salah satu nodes cluster dalam kondisi failure dan testing hanya dilakukan pada nodes yang tidak mengalami failure. Pengujian dilakukan dengan memberikan beban koneksi pada server. Berikut adalah hasil dari pengujian parameter CPU Utilization:

Tabel 3 Hasil Pengujian CPU Utilization

\begin{tabular}{|c|c|c|c|}
\hline $\begin{array}{c}\text { Jumlah } \\
\text { Koneksi }\end{array}$ & Rate & Skenario I & Skenario I \\
10 & 100 & $98,7 \%$ & $96 \%$ \\
20 & 100 & $97 \%$ & $96,7 \%$ \\
30 & 100 & $97,3 \%$ & $97,3 \%$ \\
40 & 100 & $98,2 \%$ & $98,1 \%$ \\
50 & 100 & $96,9 \%$ & $96,6 \%$ \\
\hline
\end{tabular}

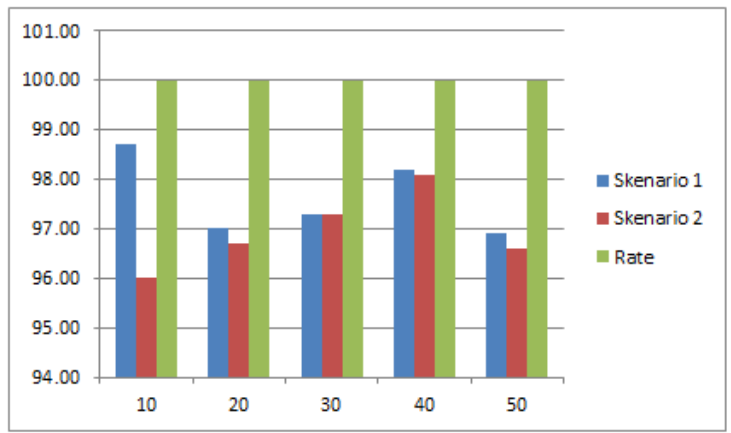

Gambar 8 Analisis CPU Utilization

Hasil pengujian CPU Utilization pada Tabel 3 dan grafik 4.2 menunjukkan bahwa semakin berat beban pengujian maka semakin mempengaruhi nilai CPU Utilization yang digunakan. Dari Tabel 3 dan grafik pada gambar 8 nilai CPU Utilization paling kecil didapat dari pengujian 10 koneksi pada server backup dengan CPU usage yang digunakan sebesar 96\% yang terdapat pada pengujian skenario kedua. Sedangkan nilai CPU Utilization paling besar didapatkan dari pemberian beban sebanyak 10 koneksi pada pengujian skenario pertama dengan nilai $98.7 \%$. Dapat disimpulkan bahwa terdapat perbedaan dari nilai CPU Utilization yang mana pada skenario pertama CPU bekerja lebih berat dibanding pada skenario kedua walaupun dengan beban koneksi yang sama.

\section{Analisis Paramater Throughput}

Throughput adalah nilai rata-rata pada pengiriman pesan yang sukses melalui sebuah link komunikasi. Data tersebut dapat dikirim melalui sebuah link physical maupun logical, atau lewat sebuah network node tertentu. Satuan untuk nilai throughput adalah bit per detik (bit/s atau bps). 
Pada pengujian ini juga dilakukan dengan dua skenario berbeda. Skenario pertama adalah testing dilakukan pada saat semua nodes cluster dalam kondisi up. Skenario kedua saat salah satu nodes cluster dalam kondisi failure dan testing hanya dilakukan pada nodes yang tidak mengalami failure. Berikut adalah hasil pengujian parameter throughput:

Tabel 4Hasil Pengujian Throughput

\begin{tabular}{|c|c|c|c|}
\hline $\begin{array}{c}\text { Jumlah } \\
\text { Koneksi }\end{array}$ & \multicolumn{2}{c}{$\begin{array}{c}\text { Skenario I } \\
\text { Kb/s }\end{array}$} & $\begin{array}{c}\text { Skenario II } \\
\text { Kb/s }\end{array}$ \\
10 & 100 & 104,1 & 102 \\
20 & 100 & 99,2 & 99,1 \\
30 & 100 & 97,6 & 97,7 \\
40 & 100 & 96,8 & 96,9 \\
50 & 100 & 96,4 & 96,1 \\
\hline
\end{tabular}

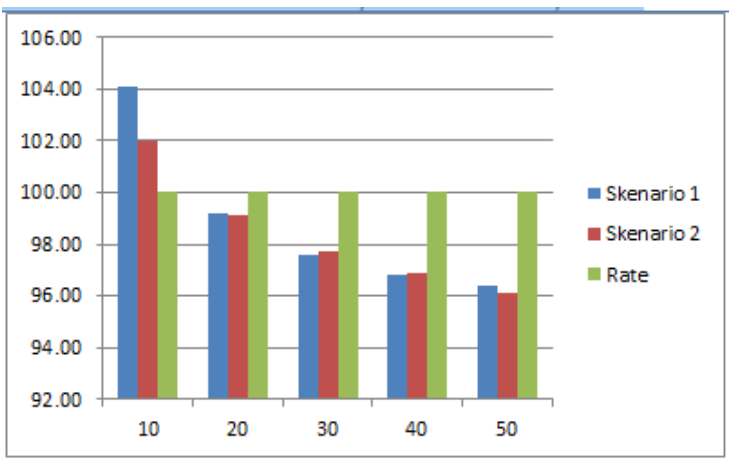

Gambar 9 Analisis Throughput

Pada Tabel 4 dan Grafik pada gambar 9 pengujian throughput didapatkan nilai terendah dari skenario kedua yaitu $96,1 \mathrm{~Kb} / \mathrm{s}$ pada beban 50 koneksi sedangkan nilai throughput tertinggi didapatkan dari pengujian skenario pertama yaitu $104,1 \mathrm{~Kb} / \mathrm{s}$ pada beban 10 koneksi. Ini menunjukkan bahwa server dalam kondisi up, nilai rata rata pengiriman pesan lebih tinggi dibandingkan pada server dalam kondisi setelah downtime/failure dan semakin besar beban koneksi maka semakin kecil nilai throughput.

\section{Analisa Akhir}

Pada bagian akhir ini yang dilakukan adalah menganalisa hasil pengujian secara keseluruhan. Seperti yang telah dilakukan pada pengujian sebelumnya diperoleh hasil yaitu performa VM yang tidak di cluster memberikan hasil yang lebih baik dari segi performa kemampuan melayani berbagai puluhan sampe ratusan koneksi dibanding VM yang di cluster.

Hal ini bisa terjadi karena sistem cluster yang dibuat merupakan cluster failover, dimana cluster failover aplikasi dan servis dijalankan hanya pada sebuah nodes, berbeda dengan cluster load balancing yang cara kerjanya adalah membagi beban secara merata pada kedua nodes. Pada cluster failover, nodes yang bekerja hanya satu sedangkan nodes lainnya hanya bertukar informasi sehingga mengetahui saat terjadi kegagalan dan siap mengambil alih aplikasi dan servis yang sedang berjalan di nodes yang mengalami failure. Untuk itu apabila dibandingkan dengan VM yang tidak di cluster performanya tidak menunjukkan hasil yang lebih baik.

Untuk menjalankan servis dan aplikasi pada cluster pada sebuah nodes harus menjalankan beberapa aplikasi dasar suatu cluster sehingga alokasi memori dan prosesornya terpakai sebagian selain oleh servis dan aplikasi yang dijalankan oleh cluster itu sendiri yaitu file server. Sedangkan pada VM yang tidak di cluster, hanya menjalankan file server tersebut tanpa harus menjalankan aplikasi dasar cluster, sehingga penggunaan memori dan prosesornya pun lebih sedikit.

Jika dilihat dari performa tiap node, VM yang di cluster memang menghasilkan performa yang tidak lebih baik yaitu kinerja CPU lebih berat 2,7\% namun hasil throughput lebih besar $8 \mathrm{~Kb} / \mathrm{s}$ dibanding VM yang tidak dicluster. Namun apabila dilihat dari segi availabilityา-nya cluster menunjukkan hasil yang jauh lebih baik. Seperti yang telah diuji bahwa pada saat terjadi failure pada sebuah node, maka nodes yang lain akan secara otomatis mengambil alih kerja nodes yang mengalami failure. Sedangkan apabila terjadi failure pada nodes yang tidak di cluster, walaupun nodes ini memilki performa yang lebih baik maka seluruh sistem akan down dan akan terjadi failure secara menyeluruh serta tidak ada yang dapat mengambil alih. Sehingga aplikasi dan servis yang dijalankan tidak dapat diakses lagi sampai terjadi perbaikan. Jadi, untuk perbandingan dari performa tiap nodes cluster menghasilkan performa yang tidak lebih baik dibandingkan node yang tidak di cluster namun dari segi availabilityา-nya terkait dengan keamanan dan kehandalan sistem ini menunjukkan hasil yang lebih baik.

\section{KESIMPULAN}

Berdasarkan penelitian yang dilakukan, maka dapat diambil kesimpulan bahwa perancangan system failover clustering pada web server berbasis cloud computing ini berhasil dilakukan dengan tahapan penelitian yakni, perancangan sistem dan pengujian sistem. system failover clustering telah berhasil dibangun diatas platform berbasis proxmox yang didalamnya terpasang sistem operasi ubuntu server. hasil yang didapatkan cukup mumpuni dari segi skalabilitas dan availability dalam hal pelayanan dan keamanan data serta dapat menangani masalah downtime.

\section{Daftar Pustaka}

[1] Lysy C. Moleong, Arthur M. Rumagit, dan Brave A. Sugiarso, " Implementasi Cluster Computing Untuk Render Animasi", Teknik elektro dan komputer, pp 1-8, 2013 
[2] Alexander F.K. Siberu "Web Programming Power Pack", Yogyakarta, Mediakom, 2013

[3] Iwan Sofana,"Cloud Computing Teori dan Praktik", Bandung, Informatika, 2012.

[4] I Putu Agus eka Pratama,"Smart City Beserta Cloud Computing dan Teknologi-teknologi Pendukung Lainnya", Bandung, Informatika, 2014.

[5] Nanang Purnomo dan Melwin Syafrizal," Failover Cluster Server Dan Tunneling Eoip Untuk Sistem Disaster Recovery", Seminar Nasional Teknologi Informasi dan Multimedia, issn:2302-3805, 19 Januari, 2013

[6] Muhammad Aidi Ali" Analisis Optimalisasi Pelayanan Konsumen Berdasarkan Teori Antrian pada Kaltimgps.com di Samarinda. Ejournal Ilmu Administrasi Bisnis, volume 2, nomor 2, 2004 :34-357. (Diakses pada hari Sabtu, tanggal 15 April 2017 pukul 17.00 WITA).
[7] Abdul Rouf," Pengujian Perangkat Lunak Dengan Menggunakan Metode White Box Dan Black Box", Sistem Informasi - STMIK HIMSYA Semarang .

[8] Janner, S."Rekayasa Perangkat Lunak." Yogyakarta: Andi, 2010

[9] Sutabri, T,"Analisis Sistem Informasi". Yogyakarta: Andi, 2012..

[10] Peni Nala Sari,"Pengertian Back Up Data, Downtime, dan Back Up Online". 12 Oktober 2012. 